\title{
Initial Growth of Peanut Cultivars at Presence of Different Sugarcane Straw Quantities
}

\author{
Micheli Satomi Yamauti ${ }^{1}$, Arthur Arrobas Martins Barroso ${ }^{1}$, Paulo Roberto Fidelis Giancotti ${ }^{1} \&$ Pedro Luis da \\ Costa Aguiar Alves ${ }^{1}$ \\ ${ }^{1}$ Department of Applied Biology to Agropecuary, São Paulo State University (Unesp), 14884-900, Brazil \\ Correspondence: Micheli Satomi Yamauti, Department of Applied Biology to Agropecuary, São Paulo State \\ University (Unesp), 14884-900, Brazil. E-mail: micheliyamauti@yahoo.com.br
}

Received: March 20, 2012 Accepted: April 1, 2012 Online Published: May 22, 2012

doi:10.5539/jas.v4n7p121 URL: http://dx.doi.org/10.5539/jas.v4n7p121

\begin{abstract}
This work was carried out to evaluate the effect of sugarcane straw on plants emergence and some characteristics of initial growth of peanut plants in boxes with soil as substrate. The treatments constituted by straw quantities of: $0,4,8,12,16$ and $20 \mathrm{tha}^{-1}$ and the five cultivars tested were IAC 213, IAC 503, IAC 505, IAC 886 and IAC Tatu ST. The experiment was arranged in a completely randomized design, in a factorial arrangement of $6 \times 5$ with four replications. At 30 days after sowing were evaluated chlorophyll content, height, emergence of plants, number of leaves, total foliar area, foliar area per plant, leaf, stem, aerial part total and per plant dry mass. Data obtained were submitted to $F$ in variance analysis test and means were compared with Tukey at $p>0.05$. The same data were padronized and analyzed by hierarchical cluster analysis utilizing as the similarity coefficient the simple Euclidian distance and as linkage method the Ward Method. The straw did not affect the cultivars growth studied and the straight cultivar IAC Tatu ST had the major initial growth if compared to the other.
\end{abstract}

Keywords: Arachis hypogaea, growth, multivariate analysis

\section{Introduction}

In Brazil, peanut culture occurs, overall, in sugarcane renovation areas, mainly at São Paulo state, major sugarcane national producer, and this fact places the country between bigger worldwide peanut producers (Dias et al., 2009). Recently, because of legislation, sugarcane agroindustry located in São Paulo have to reduce gradually the sugarcane burning, consequently occurs an increasing in using sugarcane harvesters that drops on soil surface, after harvest, approximately $15 \mathrm{Mg} \mathrm{ha}^{-1}$ of dry mass, which forms a straw layer of 8 to $10 \mathrm{~cm}$ of density (Bolonhezi et al., 2007).

Studies about implementing viability of peanut cultivation, in no tillage system or in conservationist management, are few (Crusciol \& Soratto, 2007). However, results indicate that development of this technology will allow peanut in no tillage system, in green-cane harvest areas (Bolonhezi et al., 2007). According to these authors, the conservationist management adoption in these conditions provides a reduction of $30 \%$ on soil preparation cost.

The cover crops can presents stimulating or reducing effect in seed germination and seedlings emergence, depending on donor straw specie and cover density (Canossa et al., 2007). This residue alters the physical conditions of local microclimate in function of quality and quantity of incident light, reducing thermic amplitude (Ramos et al., 2008) and affecting the emergence and growth plants, by dormancy and seed germination interference (Trezzi \& Vidal, 2004). According to Martins et al. (1999), to minimize effects of straw quantities alteration on treatments, the studies must have minor duration possible, even so the decomposition rate depends of soil and climate conditions.

In this context, according to Ajay et al. (2012) multivariate analytical tools as clustering and PCA analysis are gaining importance classifying genotypes into different groups and identifying pattern among them.

The hypothesis of this work is that the straw presence in conservationist systems affects the peanut growth. So, the aim of this work was to evaluate the sugarcane straw effect on seedling emergence and in some characteristics in initial growth of five peanut cultivars and separate them using their traits. 


\section{Material and Methods}

The experiments were realized using as experimental unit boxes with 15 liters capacity with dimensions of $36 \mathrm{x}$ $30 \times 15 \mathrm{~cm}$ and area of $0,108 \mathrm{~m}^{2}$, containing as substrate soil of clayey Red Latosol. The experimental design was completely randomized, in factorial scheme $6 \times 5$, with four replications. The treatments were constituted by straw sugarcane quantities $\left(0,4,8,12,16\right.$ and $\left.20 \mathrm{Mg} \mathrm{ha}^{-1}\right)$ and five cultivars IAC 213, IAC 503, IAC 505, IAC 886 and IAC Tatu ST, totalizing 30 treatments.

After mechanical sugarcane harvest of cultivar RB 855453, and before herbicide spraying, it was collected the remaining straw on soil surface, with a posterior drying process in a forced air circulation chamber under $60{ }^{\circ} \mathrm{C}$ and cut in minor fragments.

After sowing of ten seeds of each cultivar by box, it was made the cover with sugarcane straw, that were weighed according to straw density proposed.

At 30 days after sowing, it were evaluated on peanut plants: emergence, total relative chlorophyll content (Spad 502 , Minolta ), height, number of leaves, total foliar area, foliar area per plant, leaves, stem aerial part total dry mass and per plant. The total values were relating to what were collected in box area of $0,108 \mathrm{~m}^{2}$. All data were submitted to variance analysis $F$ test and medias were compared with Tukey test $p>0,05$.

To multivariate analysis, the same data were standardized and applied cluster analysis by hierarchical method, using Euclidian distance as similarity coefficient and as linkage method Ward's method, using the program Statistica versão 8.0.

\section{Results and Dicussion}

The cultivar did not show correlation with straw quantity for none variables analyzed (Table 1).

Table 1. Effect of different straw quantities on some peanut characteristics 30 days after sowing

\begin{tabular}{|c|c|c|c|c|c|c|c|c|c|c|c|c|}
\hline & $\begin{array}{c}\text { Total } \\
\text { foliar area } \\
\left(\mathrm{cm}^{2} 0,1 \mathrm{~m}^{-2}\right) \\
\end{array}$ & $\begin{array}{c}\text { Foliar area } \\
\text { planta }^{-1} \\
\left(\mathrm{~cm}^{2}\right)\end{array}$ & $\begin{array}{l}\text { Height } \\
(\mathrm{cm})\end{array}$ & $\begin{array}{c}\text { Number of } \\
\text { leaves } \\
\text { plant }^{-1} \\
\end{array}$ & $\begin{array}{c}\text { Emergence } \\
(\%) \\
\end{array}$ & $\begin{array}{c}\text { Chlorophyll } \\
\text { content } \\
\text { (UR) }\end{array}$ & $\begin{array}{c}\text { Total } \\
\text { Leaves DM } \\
\left(\mathrm{g} 0,1 \mathrm{~m}^{-2}\right) \\
\end{array}$ & $\begin{array}{c}\text { Leaves DM } \\
\text { planta }^{-1} \\
(\mathrm{~g})\end{array}$ & $\begin{array}{c}\text { Total } \\
\text { Stem DM } \\
\left(\mathrm{g} 0,1 \mathrm{~m}^{-2}\right) \\
\end{array}$ & $\begin{array}{c}\text { Stem DM } \\
\text { plant }^{-1} \\
(\mathrm{~g})\end{array}$ & $\begin{array}{c}\text { Total } \\
\text { AP DM } \\
\left(\mathrm{g} 0,1 \mathrm{~m}^{-2}\right) \\
\end{array}$ & $\begin{array}{c}\text { AP DM } \\
\text { plant }^{-1} \\
(\mathrm{~g}) \\
\end{array}$ \\
\hline \multicolumn{13}{|c|}{ Cultivar (C) } \\
\hline IAC 505 & $360,94 \mathrm{ab}$ & 50,39 a & $4,51 \mathrm{c}$ & $5,95 \mathrm{ab}$ & $70,83 a b$ & $41,87 \mathrm{a}$ & $1,72 \mathrm{bc}$ & $0,24 \mathrm{~b}$ & $1,27 \mathrm{~b}$ & $0,17 \mathrm{bc}$ & $2,61 \mathrm{~b}$ & $0,42 \mathrm{bc}$ \\
\hline IAC 213 & $300,17 \mathrm{bc}$ & $50,77 \mathrm{a}$ & $5,66 \mathrm{~b}$ & $5,49 \mathrm{bc}$ & $75,00 \mathrm{a}$ & $41,85 \mathrm{a}$ & $2,03 \mathrm{~b}$ & $0,26 \mathrm{~b}$ & $1,27 \mathrm{~b}$ & $0,16 b c$ & $3,30 \mathrm{~b}$ & $0,42 b c$ \\
\hline IAC 886 & $216,11 \mathrm{c}$ & $38,75 \mathrm{a}$ & $5,74 \mathrm{~b}$ & $5,89 \mathrm{ab}$ & $57,08 \mathrm{~b}$ & $43,53 \mathrm{a}$ & $1,45 \mathrm{c}$ & $0,26 \mathrm{~b}$ & $1,16 \mathrm{~b}$ & $0,21 \mathrm{a}$ & $2,61 \mathrm{~b}$ & $0,47 a b$ \\
\hline IAC 503 & $303,57 \mathrm{abc}$ & $47,51 \mathrm{a}$ & $5,75 \mathrm{~b}$ & $4,90 \mathrm{c}$ & $76,67 \mathrm{a}$ & $43,38 \mathrm{a}$ & $1,95 \mathrm{~b}$ & $0,24 \mathrm{~b}$ & $1,18 \mathrm{~b}$ & $0,14 \mathrm{c}$ & $3,13 \mathrm{~b}$ & $0,38 \mathrm{c}$ \\
\hline IAC Tatu ST & $413,59 \mathrm{a}$ & $85,67 \mathrm{a}$ & $7,03 \mathrm{a}$ & $6,24 \mathrm{a}$ & $78,33 \mathrm{a}$ & $40,90 \mathrm{a}$ & $2,84 \mathrm{a}$ & $0,33 \mathrm{a}$ & $1,70 \mathrm{a}$ & $0,19 a b$ & $4,54 \mathrm{a}$ & $0,53 \mathrm{a}$ \\
\hline \multicolumn{13}{|c|}{ Straw (S) } \\
\hline 0 & $278,60 \mathrm{a}$ & $69,94 \mathrm{a}$ & $3,88 \mathrm{e}$ & $5,25 \mathrm{a}$ & $67,00 \mathrm{a}$ & $43,91 \mathrm{a}$ & $1,65 \mathrm{a}$ & $0,21 \mathrm{~b}$ & $1,46 \mathrm{a}$ & $0,19 \mathrm{a}$ & $3,11 \mathrm{a}$ & $0,40 \mathrm{a}$ \\
\hline 4 & $317,72 \mathrm{a}$ & $56,91 \mathrm{a}$ & $4,96 \mathrm{~d}$ & $5,87 \mathrm{a}$ & $73,00 \mathrm{a}$ & $41,77 \mathrm{a}$ & $2,15 \mathrm{a}$ & $0,28 \mathrm{a}$ & $1,43 \mathrm{ab}$ & $0,19 \mathrm{a}$ & $3,58 \mathrm{a}$ & $0,47 \mathrm{a}$ \\
\hline 8 & $362,88 \mathrm{a}$ & $46,25 \mathrm{a}$ & $5,38 \mathrm{~cd}$ & $5,78 \mathrm{a}$ & $76,50 \mathrm{a}$ & $42,18 \mathrm{a}$ & $2,01 \mathrm{a}$ & $0,26 \mathrm{ab}$ & $1,29 a b$ & $0,17 \mathrm{a}$ & $3,30 \mathrm{a}$ & $0,43 \mathrm{a}$ \\
\hline 12 & $351,83 \mathrm{a}$ & $72,94 \mathrm{a}$ & $5,90 \mathrm{bc}$ & $5,91 \mathrm{a}$ & $67,50 \mathrm{a}$ & $41,80 \mathrm{a}$ & $2,13 \mathrm{a}$ & $0,29 \mathrm{a}$ & $1,27 \mathrm{ab}$ & $0,17 \mathrm{a}$ & $3,40 \mathrm{a}$ & $0,46 \mathrm{a}$ \\
\hline 16 & $305,75 \mathrm{a}$ & $43,26 \mathrm{a}$ & $6,53 \mathrm{~b}$ & $5,60 \mathrm{a}$ & $70,00 \mathrm{a}$ & $42,22 \mathrm{a}$ & $2,01 \mathrm{a}$ & $0,29 \mathrm{a}$ & $1,08 \mathrm{~b}$ & $0,16 \mathrm{a}$ & $3,10 \mathrm{a}$ & $0,45 \mathrm{a}$ \\
\hline 20 & 296,47 a & $38,42 \mathrm{a}$ & $7,78 \mathrm{a}$ & $5,75 \mathrm{a}$ & $75,50 \mathrm{a}$ & $41,95 \mathrm{a}$ & $2,04 \mathrm{a}$ & $0,26 \mathrm{ab}$ & $1,35 \mathrm{ab}$ & $0,19 \mathrm{a}$ & $3,39 \mathrm{a}$ & $0,46 \mathrm{a}$ \\
\hline $\mathrm{F}_{\mathrm{C}}$ & $6,65 * *$ & $1,58^{\mathrm{NS}}$ & $25,23 * *$ & $9,94 * *$ & $4,45 * *$ & $1,49^{\mathrm{NS}}$ & $18,44 * *$ & $9,55 * *$ & $7,01 * *$ & $5,87 * *$ & $17,20 * *$ & $9,44 * *$ \\
\hline $\mathrm{F}_{\mathrm{S}}$ & $1,08^{\mathrm{NS}}$ & $0,84^{\mathrm{NS}}$ & $47,84 * *$ & $1,81^{\mathrm{NS}}$ & $0,82^{\mathrm{NS}}$ & $0,65^{\mathrm{NS}}$ & $1,89^{\mathrm{NS}}$ & $4,92 * *$ & $2,18^{\mathrm{NS}}$ & $0,97^{\mathrm{NS}}$ & $0,92^{\mathrm{NS}}$ & $1,63^{\mathrm{NS}}$ \\
\hline $\mathrm{F}_{\mathrm{C}} \times \mathrm{F}_{\mathrm{S}}$ & $0,861^{\mathrm{NS}}$ & $1,02^{\mathrm{NS}}$ & $1,57^{\mathrm{NS}}$ & $0,83^{\mathrm{NS}}$ & $0,72^{\mathrm{NS}}$ & $0,95^{\mathrm{NS}}$ & $0,61^{\mathrm{NS}}$ & $0,91^{\mathrm{NS}}$ & $0,80^{\mathrm{NS}}$ & $0,74^{\mathrm{NS}}$ & $0,80^{\mathrm{NS}}$ & $1,07^{\mathrm{NS}}$ \\
\hline $\mathrm{CV} \%$ & 44,07 & 12,3 & 15,09 & 14,15 & 27,79 & 10,62 & 20,75 & 22,54 & 30,94 & 32,41 & 25,01 & 20,38 \\
\hline $\mathrm{DMS}_{\mathrm{C}}$ & 112,93 & 56,32 & 0,69 & 0,64 & 15,99 & 3,61 & 0,48 & 0,01 & 0,33 & 0,04 & 0,62 & 0,07 \\
\hline $\mathrm{DMS}_{\mathrm{P}}$ & 129,43 & 64,54 & 0,79 & 1,58 & 39,17 & 4,13 & 0,54 & 0,05 & 0,37 & 0,05 & 0,79 & 0,02 \\
\hline
\end{tabular}

Means followed by different letters at column differs significant by Tukey test $p>0,05 . * *$ Significant at $1 \%$ of probability by F test. NS - No significant.

The cover can present a stimulating or reducing effect on seed germination and seedling emergence, depending on donor straw specie and cover density (Canossa et al., 2007). However, in this study, the plants emergence was not affected by straw quantity, independently from cultivar. Thus, the straw did not present none effect on peanut emergence and did not create a physical barrier to its plants, as happens to some weed species, as Brachiaria decumbens and Sida spinosa (Correia e Durigan, 2004). The physical effect of straw reduces the chances of plants surviving with small store in seeds (Pitelli and Durigan, 2001), which is not the case of peanut, that presents seeds relatively bigger. Nevertheless, in similar study, Ramos et al. (2008) found reduction on peanut seedling emergence with increasing straw, this difference can be explained by cultivars and conditions during the experiment that were different, in the present experiment in general, the Tatu cultivar was less affected by straw. 
Analyzing cultivars independently from present straw, the minor emergence was observed on IAC $886(57.08 \%)$, distinguishing from IAC 213, IAC 503 and IAC Tatu ST (mean of 76.7\%), while IAC 505 presented intermediate behavior $(70.8 \%)$ (Table 1$)$.

The relative chlorophyll content was not affected by straw and there was no difference among cultivars to this variable (Table 1).

Analyzing the height of plants, independently of straw quantity tested, the biggest cultivar it was IAC Tatu ST, this was expected cause it is a specie with bunch growth habit, while the other cultivars have running growth habit, among them the cultivar with lesser height it was IAC 505 (Table 1). Analyzing the straw quantity, independently of tested cultivar, with increase of straw quantity there was increase on height plants. Similar results were encountered by Ramos et al. (2008) studying the cultivars IAC-Caiapó, Runner 886 and Tatu. According to Calegari et al. (1998), due to the shading on crops, and also due to competition by a canopy position, the plants can be taken to etiolation. This happens due to some changes on plants development as result from competitive effect, that can occur in initial stage of development, since these plants have ability of perceive early alterations on length of luminous wave resulting from straw presence or plants in proximity (Radosevich et al., 1997). There are reports from agriculturists describing effects of straw presence in plants, as yellowing, etiolation, development reduction and decrease on yield crops (Maciel et al., 2003).

Independently of straw quantity imposed, the cultivars IAC Tatu ST, IAC 505 and IAC 503 obtained higher foliar area total, which is an important characteristic for being a indicative parameter of crop yield, because the photosynthetic process depends on luminous interception and its conversion in chemical energy (Favarin et al., 2002). According to these authors, the foliar area of a plant is the base of the potential crop yield. However, when analyzed foliar area per plant, there was no difference between cultivars, even having difference in number of leaves per plant, of which the cultivars IAC Tatu ST, IAC 505 and IAC 886 presented greater number, but this did not results in greater foliar area. So, can be inferred that cultivar IAC 503 has less leaves, but these present greater foliar area (Table 1).

The cultivar with higher total dry mass was IAC Tatu ST and, with the lesser, were IAC 886 and IAC 505, independently of straw quantity. To the total dry mass of leaves and stem per plant the cultivar IAC Tatu ST obtained higher values when compared to the other cultivars with running growth habit. Analyzing the stem dry mass per plant there was better development to IAC 886 and IAC Tatu ST, while to aerial part dry mass per plant the cultivar with higher values were IAC 886 and IAC Tatu ST, and when analyzed the total aerial part dry mass, the higher accumulation was from cultivar IAC Tatu ST (Table 1).

Although, independently of straw presence, it can verify that the initial growth change with the cultivars. Even do not reaching crop productions in this experiment, data agree with Grichar and Smith (1991) that cites that production results can be subjected to conduct characteristic of peanut cultivars.

Utilizing the multivariate analysis on all data, there was the formation of four groups (Figure 1). In group 1 (G1) were reunited the treatments involving the cultivar IAC Tatu ST, so, does not matter the straw quantity, this cultivar had the higher growth compared to the others and the straw quantity had similar effects on analyzed variables, this result was expected because it is a cultivar with a bunch growth habit, that obtained advantage on initial growth related to the other cultivars, that had running growth habit. In group 2 (G2) there is the cultivar IAC 886, do not matter the straw quantity, and the cultivar IAC 505 being similar to its, demonstrating that, to the analyzed variables, this two cultivars had better performance than the others. Then in group 3 (G3) there is the presence of IAC 503 and IAC 213 that obtained, among all tested cultivars, the poor performance. In group 4 (G4) there are the cultivar controls IAC 505, IAC 213, IAC 886 and IAC 503, that present smaller growth. This result can be due to the fact of straw presence which can be created favorable conditions to initial growth of these peanut cultivars. But, despite the differences, the groups G2, G3 and G4 are also, someway, similar among itselves, and the cultivar IAC Tatu ST, belonging to G1, surpass to the others, standing isolated (Figura 1). Possibly this can be explained by the different growth habit of these cultivars.

Observing the principal components graph (ACP), the first axis explains 45,67\% data variation, and the analyzed variables total foliar area (TFA), foliar area per plant (FA/Pl), height (HE), number of leaves (Num L), germination (Germ), total leaf dry mass (TLDM), leaf dry mass per plant (LDM/Pl), total stem dry mass (TSDM), stem dry mass per plant (SDM/Pl) and aerial part dry mass (APDM) had a strong relationship between them except the chlorophyll content. The cultivar IAC Tatu-ST, do not matter straw quantity, presented the highest values on these variables, because these are closer to the variable points in the graph, confirming the results obtained. Then the second axis, explains $20.7 \%$ data variation. 


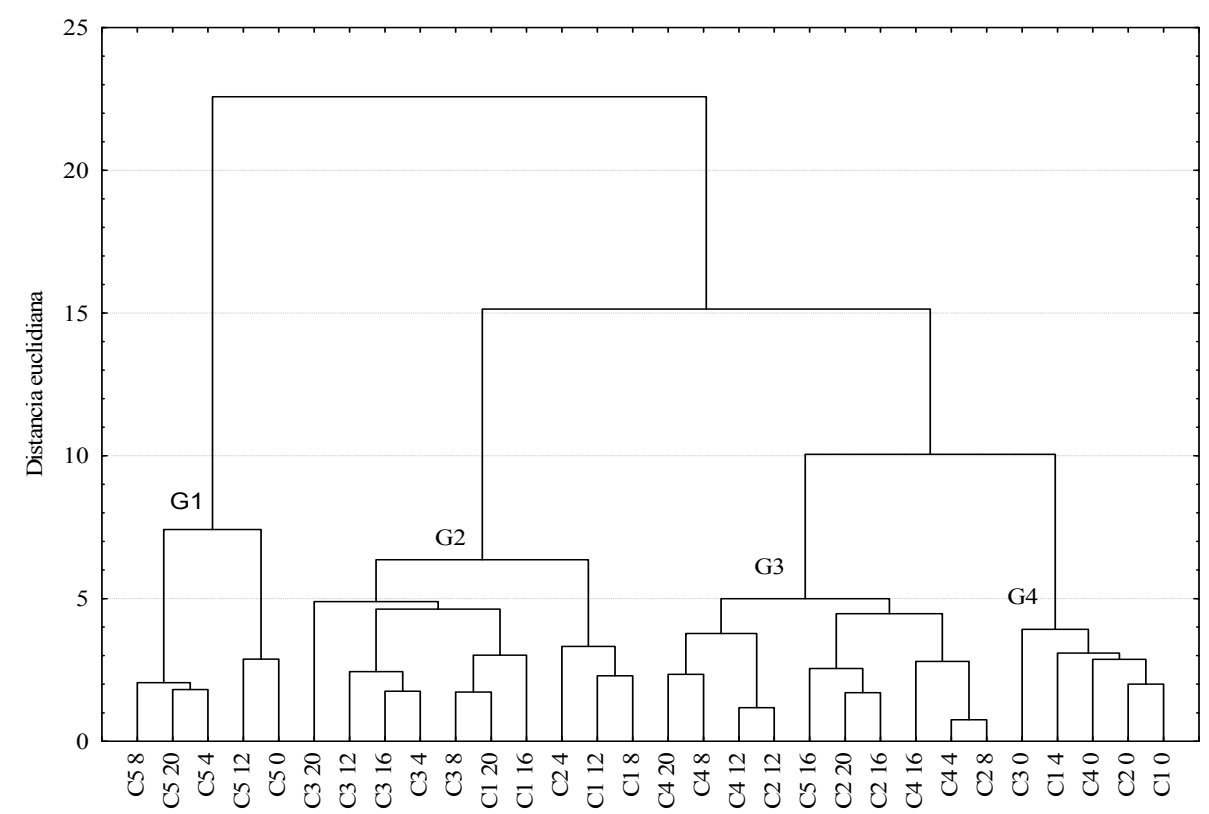

Figure 1. Cluster analysis by Ward method to peanut cultivars according to different straw quantities. (Cultivars: C1 - IAC 505; C2 - IAC 213; C3 - IAC 886; C4 - IAC 503; C5 - IAC Tatu ST) - (Straw quantities: 0 - 0 tha $^{-1} ; 4$ $\left.-4 \mathrm{t} \mathrm{ha}^{-1} ; 8-8 \mathrm{tha}^{-1} ; 12-12 \mathrm{t} \mathrm{ha}^{-1} ; 16-16 \mathrm{tha}^{-1} ; 20-20 \mathrm{t} \mathrm{ha}^{-1}\right)$

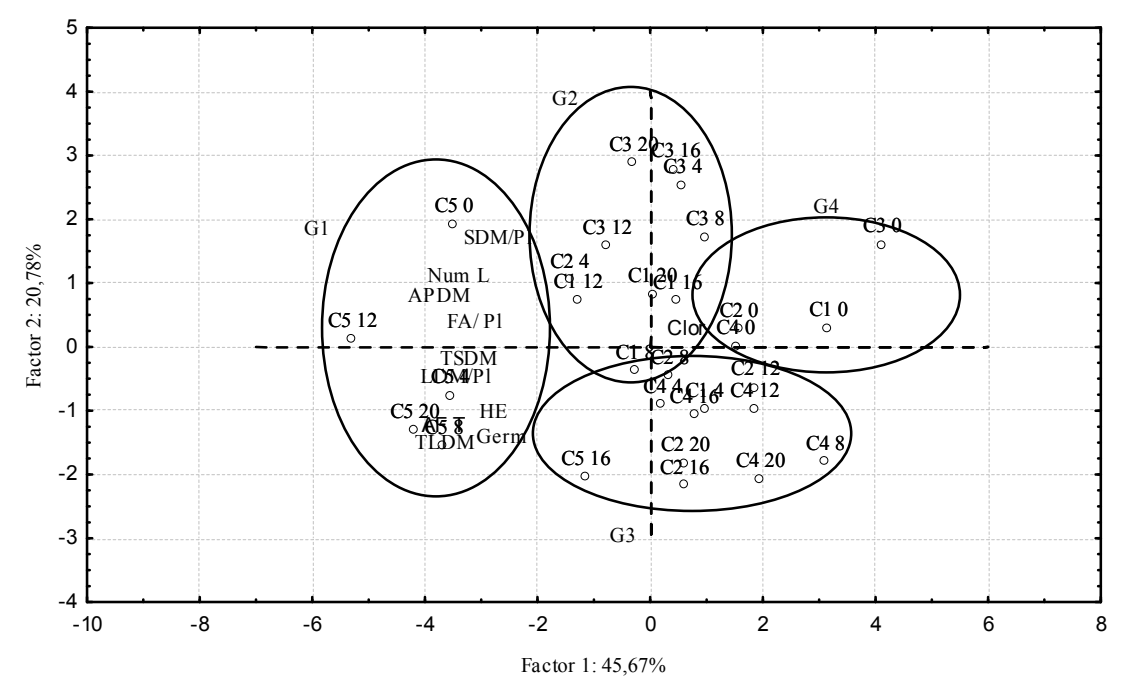

Figure 2. Graph dispersion of principal components analysis to variables analyzed in five peanut cultivars with absence and presence of straw in different quantities. (TFA - Total foliar area; FA/Pl - Foliar area per plant; HE

- Height; Num L - Number of leaves; Germ - germination; Chlor - chlorophyll content; TLDM - total leaf dry mass; LDM/P1 - leaf dry mass per plant; TSDM - total stem dry mass; SDM/Pl - stem dry mass per plant; APDM aerial part dry mass). (Cultivars: C1 - IAC 505; C2 - IAC 213; C3 - IAC 886; C4 - IAC 503; C5 - IAC Tatu ST) -

(Straw quantities: $0-0 \mathrm{tha}^{-1} ; 4-4 \mathrm{tha}^{-1} ; 8-8 \mathrm{tha}^{-1} ; 12-12 \mathrm{tha}^{-1} ; 16-16 \mathrm{tha}^{-1} ; 20-20 \mathrm{tha}^{-1}$ ).

From these results we can expect that do not have problems on cultivars development due to straw presence, since of all evaluated characteristics, only height and leaf dry mass per plant were affected by the straw quantity, disagreeing to control; besides, through these multivariate analysis there are similarities among different straw quantities to different cultivars. According to Bolonhezi et al. (2007) experiments prove that emission and establishment of peanut reproductive structures are not affected by residues presence on soil surface or by the lack of soil management, in this case an important aspect, cause it can expect that as in study if the initial growth was not affected by straw presence, neither production could be. Similar to Bolonhezi et al. (2007) that did not find difference from conventional and no tillage system to peanut production on most assays and, in the assays with difference, no tillage system can improve of 6.5 to $9 \%$ in grain yield index. Similar results were found in long duration research realized by Grichar (1998). Even though there are results that mention significant increase pod production, when using conservationist system in soil (Tasso Junior, 2003), according to Crusciol and 
Soratto (2007) the cover specie and the mechanical management straw did not influence the nutrition and peanut productivity in no tillage system.

\section{Conclusion}

The sugarcane straw presence did not prejudice the emergence and initial growth of tested cultivars; Leaving out of account the straw presence, there was difference among cultivars, and the cultivar IAC Tatu ST was the cultivar with the highest initial growth.

\section{References}

Ajay, B. C., Gowda, M. V. C., Rathkumar, A. L., Kusuma, V. P., Fiyaz, R. A., Holajjer, P., ... Babu, H. P. (2012). Improving Genetic Attributes of Confectionary Traits in Peanut (Arachis hypogaea L.) Using Multivariate Analytical Tools. Journal of Agricultural Science, 4(3), 247-258. http://dx.doi.org/10.5539/jas.v4n3p247

Bolonhezi, D., Mutton, M. A., \& Matins, A. L. M. (2007). Sistemas conservacionistas de manejo do solo para amendoim cultivado em sucessão a cana crua. Pesquisa Agropecuária Brasileira, 42(7), 939-947. http://dx.doi.org/10.1590/S0100-204X2007000700005

Calegari, A., Heckler, J. C., Santos, H. P., Pitol, C., Fernandes, F. M., Hernani, L. C., \& Gaudêncio, C. A. (1998). Culturas, sucessões e rotações. In Salton, J., Hernani, L. C., Fontes, C. Z. (Eds.) Sistema Plantio Direto. O produtor pergunta, a Embrapa responde. (pp. 59-80) Dourados: Embrapa-CPAO.

Canossa, R. S., Oliveira Jr., R.S., Constantin, J., Biffe, D. F., Alonso, D. G., \& Franchini, L. H. M. (2007). Profundidade de semeadura afetando a emergência de plântulas de Alternanthera tenella. Planta Daninha, 25(4), 719-725. http://dx.doi.org/10.1590/S0100-83582007000400008

Correia, N. M., \& Durigan, J. C. (2004). Emergência de plantas daninhas em solo coberto com palha de cana-de-açúcar. Planta Daninha, 22(1), 11-1. http://dx.doi.org/10.1590/S0100-83582004000100002

Crusciol, C. A. C., \& Soratto, R. P. (2007). Nutrição e produtividade do amendoim em sucessão ao cultivo de plantas de cobertura no sistema plantio direto. Pesquisa Agropecuária Brasileira, 42(11), 1553-1560. http://dx.doi.org/10.1590/S0100-204X2007001100006.

Dias, T. C. S., Alves, P. L. C. A., Pavani, M. C. M. D., \& Nepomuceno, M. (2009). Efeito do espaçamento entre fileiras de amendoim rasteiro na interferência de plantas daninhas na cultura. Planta Daninha, 27(2), 221-228. http://dx.doi.org/10.1590/S0100-83582009000200002.

Favarin, J. L., Dourado Neto, D. D., Garcia, A. G., Nova, N. A. V., \& Favarin, M. G. G. V. (2002). Equações para a estimativa do índice de área foliar do cafeeiro. Pesquisa Agropecuária Brasileira, 37(6), 769-773.

Grichar, W. J., \& Smith, O. D. (1991). Effects of tillage systems on Southern blight and pod yield of five runner peanut genotypes. Peanut Science, 18(1), 144-147. http://dx.doi.org/10.3146/i0095-3679-18-2-19

Grichar, W. J. (1998). Long term effects of three tillage systems on peanut grade, yield, and stem rot development. Peanut Science, 25(1), 59-62. http://dx.doi.org/10.3146/i0095-3679-25-2-1

Maciel, C. D. G., Corrêa, M. R., Alves, E., Negrisoli, E., Velini, E. D., Rodrigues, J. D., Ono, E. O., \& Boaro, C. S. F. (2003). Influência do manejo da palhada de capim-braquiária (Brachiaria decumbens) sobre o desenvolvimento inicial de soja (Glycine max) e amendoim-bravo (Euphorbia heterophylla). Planta Daninha, 21(3), 365-373. http://dx.doi.org/10.1590/S0100-83582003000300003

Pitelli, R. A., \& Durigan, J. C. (2001). Ecologia das plantas daninhas no sistema plantio direto. In Rossello, R. D. (Ed.) Siembra directa en el cono sur (pp.203-210) Montevideo: PROCISUR.

Radosevich, S., Holt, J., \& Ghersa, C. (1997). Weed ecology: implications for management. (2.ed.) New York: Wiley, (p. 588).

Ramos, N. P., Novo, M. C. S. S., Lago, A.A., \& Marin, G. C. (2008). Emergência de plântulas e crescimento inicial de cultivares de amendoim sob resíduos de cana-de-açúcar. Revista Brasileira de Sementes, 30(1). 190-197. http://dx.doi.org/10.1590/S0101-31222008000100024

Tasso Junior, L. C. (2003). Cultura da soja, milho e amendoim sob diferentes sistemas de manejo do solo em área com palha residual de colheita mecanizada de cana crua. (Agri.). Dissertation. Universidade Estadual Paulista, Jaboticabal.

Trezzi, M. M., \& Vidal, R. A. (2004). Potencial de utilização de cobertura vegetal de sorgo e milheto na supressão de plantas daninhas em condição de campo: II - Efeitos da cobertura morta. Planta Daninha, 22(1), 1-10. http://dx.doi.org/10.1590/S0100-83582004000100001 